\title{
I mpact of dietary fats on fatty acids profile of threatened Asian cafish (Clarias batradhus, Linnaeus, 1758)
}

\author{
P.P. Srivastava, ${ }^{1,2}$, Akhilesh K. Yadav ${ }^{3}$, Shipra Chowdhary ${ }^{1}$, Pradeep Shrivastava ${ }^{4}$, R. Dayal ${ }^{1}$, G.Venkateshwarlu ${ }^{5}$ and \\ W. S. Lakra ${ }^{1,6}$ \\ ${ }^{1}$ National Bureau of Fish Genetic Resources, Canal Ring Road, Teli Bagh, Lucknow - 226 002, UP, India. ${ }^{2}$ Fish Nutrition, Biochemistry and Physiology \\ Division, Central Institute of Fisheries Education, Panch Marg, Off Yari Road, Mumbai-400 061, MS, India. ${ }^{3}$ Aquaculture Research Training Unit, \\ National Bureau of Fish Genetic Resources, Chinhat, Faizabad Road, Lucknow- 227 105, UP, India. ${ }^{4}$ Department of Applied Aquaculture and Zoology, \\ Barkatullah Viswavidyalaya, Bhopal, MP, India. ${ }^{5}$ Fisheries Resources, Harvest and Post-harvest Division, Central Institute of Fisheries Education, Panch \\ Marg, Off Yari Road, Mumbai-400 061, MS, India. ${ }^{6}$ Present Address : Central Institute of Fisheries Education, Panch Marg, Off Yari Road, Mumbai-400 \\ 061, MS, India.
}

\section{ARTICLE INFO}

Article history:

Received on: 14/01/2014

Revised on: 26/08/2014

Accepted on: 25/10/2014

Available online: 30/10/2014

\section{Key words:}

Dietary fats, fatty acids, carcass, Clarias batrachus, Asian catfish, grow-out.

\begin{abstract}
Different fats in the diets were used to examine their impact on the fatty acid profile of asian catfish(Clarias batrachus) on feeding the diets for 12-weeks. There were seven treatments (FISOL, BETAL, SOYAL, LINOL, MIXOL, SATOL and NATFO containing Fish oil, Beef tallow, Soybean oil, Linseed oil, Mixed oil (i.e. containing in 1:1:1:1 ratio of Fish oil, Beef tallow, Soybean oil, Linseed oil), Vegetable oil and minced chicken meat as natural food, respectively, each with three replications, stocked with 30 grow-out having an initial average weight $55.83 \pm 3.14 \mathrm{~g}$ in a circular plastic pools (capacity $300 \mathrm{~L}$ ). The six feeds were formulated with basic ingredients (Soybean meal, 35\%; soluble starch, 29\%; Casein, 19.5\%; carboxy - methyl - cellulose, 2\%; papain, $0.5 \%$; vitamin and mineral mix, $4.0 \%)$ with iso-energetic $(19.55 \mathrm{~kJ} / \mathrm{g}, \mathrm{F} 1-\mathrm{F} 6$ ) diets and results were compared with natural food (F7) fed fishes. Each diet was hand fed two times daily during experimental period to triplicate homogenous groups of 30 fish. The muscle fillet polyunsaturated fatty acids (PUFA) content varied with different lipid levels suggesting that the dietary fat has impact on deposition of fatty acid in flesh. The muscle unsaturated fatty acids, including Docosa-hexaenoic acid (22:6n3, DHA) level, were comparatively higher in MIXOL diet followed by NATFO and LINOL diets, indicating selective deposition of fatty acids. It was concluded that addition of various fats in the diet has role in the composition of carcass fatty acid profile in Clarias batrachus and the MIXOL (Fish Oil : Tallow : Soybean Oil : Linseed Oil :: $1: 1: 1: 1 \mathrm{w} / \mathrm{w}$ ) could be safely used for better and/ or more deposition of healthy fatty acids (EPA and DHA) which are considered as human health beneficial fatty acids and also useful to economize the cost of the broodstock feed.
\end{abstract}

\section{INTRODUCTION}

It is documented[1] in fish cultured in intensive farming systems need all energy nutrients in the diet. The requirements of major nutritional ingredients like protein and gross energy is a requisite for the feed formulation of a balanced diet for the culturable fishes. In India there is a huge source for the production of economically viable plant sources e.g. numerous de-oiled cakes rich in essential fatty acid (EFA) which can be properly utilized as source of fats in predatory /carnivorous fish feed not only for growth performances but also for ovarian tissue growth and maturation through dietary interventions. The uses of such, mentioned above, agro by-products, like various de-oiled cakes etc. can be successfully used in place of animal origin fats as energy source and EFA. Thus, the fatty acid composition of

* Corresponding Author

Mail id: ppsicar@gmail.com,

Fax +91-22 26361573; ph: +91-22-26361446 plant source ingredients have a rich source of EFA which can be used for carnivore fish feeding system/ nutrition. Obviously these can be very well used in place of animal fat, and studies can be made for nutrients deposition in carcass and also help in maturation of the ovary as well. Sarowar et al. [2] have studied the effects of various diets on survival and growth of Channa striatus. Influence of dietary protein/ lipid ratio and requirement has been well documented in C. striatus [3]. Since the fish oil (FO) is not only expensive but becoming least available, there is really an urgent requirement to assess the nutritional potential of other naturally available sources of lipid from both plants and animals. World widely, there is pressure to replace FO with less expensive plant fat source. Replacement of FO by vegetable source oils had been proved in number of fishes without impairing the growth. [4-10]. The metabolic impact of various dietary oils of fish are still not very clearly worked out, in catfishes as the changes in dietary oils may lead to imbalances in the ratios of essential or non-essential fatty acids, and may be affecting fatty acid profile of the carcass. 
Fish lipids are very importance because of better levels of polyunsaturated fatty acids (PUFA), being reported to reduce the cardiac diseases [11] and lower triacylglycerol levels in plasma [12]. In addition, to these they reduce the physiological symptomatic alterations $[13,14]$. Lipid content and FA proximate composition in fish carcass are known to change significantly depending on the supply of feed ingredients to fish and as well as environmental conditions $[15,16]$. A study have shown that $n-3$ PUFA of marine animals changes dependent on various environmental and biological factors, such as diet of the animals, taxonomy, latitude and water, temperature at which they were caught and harvested [17]. The present study was taken up to assess the impact of different dietary lipids on the carcass fatty acid profile in the edible tissue of Asian catfish C. batrachus and also FA profile enrichment of this commercially important fish which is under threatened stage [18].

\section{MATERIALS AND METHODS}

\subsection{Feed Preparation}

Six semi-purified experimental diets were formulated to be iso-energetic iso-energetic (19.55 kJ/g, F1-F6) diets. Weighed dry ingredients and some water were poured into a mixer and the resulting dough processed in a hand pelletizer to make $2 \mathrm{~mm}$ diameter pellets. Compounded feed pellets were dried in an oven at $60^{\circ} \mathrm{C}$, packed separately and stored at $-20^{\circ} \mathrm{C}$ until used during the feeding trial. The dietary treatments were designated as FISOL (Fish oil), BETAL (Beef tallow), SOYAL (Soybean oil), LINOL (Linseed oil), MIXOL and SATOL (Vegetable oil) containing lipid source @ 10\% lipid source in all the five feeds except in MIXOL (containing FISOL, BETAL, SOYAL, LINOL in the ratio of 1: 1: $1: 1 \mathrm{w} / \mathrm{w})$ and results are compared with natural food (NATFO). Table 1 gives the summary of ingredients used in the formulation of experimental diets and proximate composition of all dietary treatments.

\subsection{Fish rearing and feeding trials}

Clarias batrachus grow-outs were hatchery bred at National Bureau of Fish Genetic Resources (NBFGR), Lucknow and shifted to the wet laboratory. Fishes were acclimated to laboratory conditions in a 1500 L capacity Fibre Reinforced Plastic (FRP) tank, feeding on crumbled pelleted feed containing a minimum of $500 \mathrm{~g}$ per $\mathrm{kg}$ crude protein for one week. Further, fishes were accustomed to aerated, $300 \mathrm{~L}$ capacity plastic pools with two - thirds filled with water and covered with plastic covers. Four hundred twenty (Replicate 3 X Feed 7 X Fish 20) grow-out ( Av. initial weight $55.83 \pm 3.14 \mathrm{~g}$ ) were randomly sampled and distributed into 21 plastic pools ( Feed 7 X Replicate $3=21$ pools) containing about $200 \mathrm{~L}$ of water. During the experiment, the fishes were fed twice a day at 10:00 and 17:00 hours ad libitum per day. The weighing of fishes during and on termination of the experimentation was carried as determined by Hasan et al. [6]. All fish were starved for $24 \mathrm{~h}$ prior to weight measurements. Rearing pools were cleaned every second day and about half of the water was replaced with fresh bore-well water to reduce the nitrogenous waste accumulated. fishes were weighed individually at the beginning and at the end of the experiment, whereas batch weighing per pool was carried out once every 2 weeks to monitor growth performance in terms of weight gain ratio alongside measuring feed consumption. At the end of the experiment after 12 weeks, surviving fishes were randomly grouped into three per tank and used to determine fatty acid profile of the fish.

\subsection{Lipid extraction}

Total lipid was extracted from muscle following Folch[19]. Muscle tissue (5g) was homogenised in 10 volume of methanol (w/v) followed by 20 volume of chloroform (w/v) in a homogenizer (ART Miccra, Germany).

The homogenate was filtered (using a funnel with a folded defatted filter paper) to recover the liquid phase and the filter residue was re-homogenised with a second volume of chloroform-methanol. The filtrate was washed with 0.2 volume (4 $\mathrm{ml}$ for $20 \mathrm{ml}$ ) of $0.9 \% \mathrm{NaCl}$ solution and phases were thoroughly mixed. The mix was poured into a separating funnel and allowed to separate. The lower chloroform phase containing lipids was collected and evaporated under vacuum in a rotary evaporator to bring down the volume to $2-3 \mathrm{ml}$. Further evaporation of chloroform was done under nitrogen stream and residue was weighed to quantify the amount of lipid extracted. The lipid residue was re-dissolved in chloroform/ methanol $(2: 1, \mathrm{v} / \mathrm{v})$ and then stored in a $25 \mathrm{ml}$ conical flask with glass stopper under nitrogen at $-20{ }^{\circ} \mathrm{C}$ until needed.

\subsection{Preparation of fatty acid methyl esters (FAME)}

The method as per AOAC[20] was followed to esterify the lipid. FAME was prepared from the isolated lipids by heating with the methanolic $\mathrm{NaOH}$ and then with $\mathrm{BF} 3$ methanol for esterification. An aliquot of $5 \mathrm{ml} \mathrm{n}$-heptane was added to recover the methyl esters in organic phase. The mixture was washed with saturated $\mathrm{NaCl}$ solution and two phases were separated using a separating funnel. The upper n-heptane phase was collected and stored in $10 \mathrm{ml}$ all glass vials until further analysis.

\subsection{Gas chromatography - mass spectrometry (GC-MS)}

Fatty acid methyl esters were separated using a Shimadzu QP2010 quadruple Gas Chromatography Mass Spectrometer (GCMS) equipped with a Carbowax (30 m x $0.25 \mathrm{~mm}$ ID; 0.25- $\mu \mathrm{m}$ film thickness) capillary column (Cromlab S.A.). Helium was used as the carrier gas. Injector and detector temperatures were set at $250{ }^{\circ} \mathrm{C}$. Injection was performed in split mode $(1: 15)$. The column temperature was programmed initially at $50^{\circ} \mathrm{C}$ for $2 \mathrm{~min}$ and then increased at a rate of $10{ }^{\circ} \mathrm{C}$ per min to a final temperature of 230 ${ }^{\circ} \mathrm{C}$. FAME was separated at constant pressure $(23.1 \mathrm{kpa})$ and peaks were identified by comparing standard mass spectra with the relative abundances of $\mathrm{m} / \mathrm{z}$ ranging from 40 to 550. The values of fatty acids are presented in peak area percentage of total identified fatty acids. 
Table 1: Ingredients composition (w/w) of feeds for Clarias batrachus.

\begin{tabular}{|c|c|c|c|c|c|c|c|c|}
\hline \multirow{2}{*}{$\begin{array}{ll}\text { Ingredtents } & \text { Feed } \\
\end{array}$} & F-1 & F-2 & \multicolumn{2}{|r|}{ F-3 } & F-4 & F-5 & F-6 & F-7 \\
\hline & FISOL & BETAL & \multicolumn{2}{|c|}{ SOYOL } & LINOL & MIXOL & SATOL & NATFO \\
\hline Soybean meal & 35.0 & 35.0 & \multicolumn{2}{|c|}{35.0} & 35.0 & 35.0 & 35.0 & - \\
\hline Starch Soluble & 29.0 & 29.0 & \multicolumn{2}{|r|}{29.0} & 29.0 & 29.0 & 29.0 & - \\
\hline Casein & 19.5 & 19.5 & \multicolumn{2}{|r|}{19.5} & 19.5 & 19.5 & 19.5 & - \\
\hline Carboxy Methyl Cellulose & 2.0 & 2.0 & \multicolumn{2}{|r|}{2.0} & 2.0 & 2.0 & 2.0 & - \\
\hline Papain & 0.5 & 0.5 & \multicolumn{2}{|r|}{0.5} & 0.5 & 0.5 & 0.5 & - \\
\hline Vitamin \& Mineral Mix. & 4.0 & 4.0 & \multicolumn{2}{|r|}{4.0} & 4.0 & 4.0 & 4.0 & - \\
\hline Fish Oil & 10.0 & - & \multirow{2}{*}{\multicolumn{2}{|c|}{$\begin{array}{l}- \\
-\end{array}$}} & - & 2.5 & - & - \\
\hline Tallow & - & 10.0 & & & - & 2.5 & - & - \\
\hline Soybean Oil & - & - & \multicolumn{2}{|r|}{10.0} & - & 2.5 & - & \\
\hline Linseed Oil & - & - & \multicolumn{2}{|r|}{ - } & 10.0 & 2.5 & - & - \\
\hline Saturated Oil & - & - & \multicolumn{2}{|r|}{ - } & - & - & 10.0 & - \\
\hline $\begin{array}{l}\text { Live Fish/ Natural Food } \\
\text { (minced chicken) }\end{array}$ & - & - & \multicolumn{2}{|r|}{ - } & - & - & - & 100.0 \\
\hline \multicolumn{9}{|c|}{$\begin{array}{l}\text { FISOL = Fish Oil; BETAL = Beef Tallow; SOYOL = Soybean Oil; LINOL = Linseed Oil; MIXOL = Mixed Oil ( Fish Oil : Tallow : Soybean Oil : } \\
\text { Linseed Oil :: } 1: 1: 1: 1 \mathrm{w} / \mathrm{w}) ; \text { SATOL = Saturated Oil; NATFO = Natural Food }\end{array}$} \\
\hline Fatty Acid & Emperical formula & $\begin{array}{c}\text { F1 } \\
\text { (FISOL) }\end{array}$ & $\begin{array}{c}\text { F2 } \\
\text { (BETAL) }\end{array}$ & $\begin{array}{c}\text { F3 } \\
\text { (SOYAL) }\end{array}$ & $\begin{array}{c}\text { F4 } \\
\text { (LINOL) }\end{array}$ & $\begin{array}{c}\text { F5 } \\
\text { (MIXOL) }\end{array}$ & $\begin{array}{c}\text { F6 } \\
\text { (SATOL) }\end{array}$ & $\begin{array}{c}\text { F7 } \\
\text { (NATFO) }\end{array}$ \\
\hline Linoleic acid & C18:2(n-6) & 9.07 & 20.59 & 12.74 & 18.42 & 17.55 & 12.75 & 15.37 \\
\hline Alpha-linolenic acid & C18:3(n-3) & 0.31 & 0.82 & 0.37 & 0.77 & 0.46 & - & 1.02 \\
\hline Eicosenoic acid & C20:1(n-9) & 0.38 & 0.98 & 1.02 & 0.91 & 0.73 & - & 0.88 \\
\hline Arachidonic acid & C20:4(n-6) & 4.75 & 4.38 & 3.85 & 5.21 & 8.91 & 4.58 & 3.41 \\
\hline Eicosapentaenoic acid & $\mathrm{C} 20: 5(\mathrm{n}-3)$ & - & 0.76 & - & 0.70 & 3.29 & - & 0.52 \\
\hline Docosahexaenoic acid & $C 22: 6(n-3)$ & 0.57 & 0.59 & 0.27 & 0.66 & 0.78 & - & 0.68 \\
\hline
\end{tabular}

\section{RESULTS AND DISCUSSION}

\subsection{Total lipid content}

The results on total lipid content $(\%)$ measured in the muscle tissue of Clarias batrachus significant differences $(\mathrm{p}<0.05)$ were observed in different feedings (F1-F7) fed fishes. The total lipid content in muscle was found to be in the range of $2.8 \pm 0.23$ to $3.1 \pm 0.17 \%$. According to the one suggested by Kleimenov[21], fishes belongs to the group of low fat fishes having an average lipid content of $2-8 \%$. The lipid contents in the body of fishes as well as prey animals have been reported to be very high [22]. As the fish consume prey with medium lipid content, the additional dietary lipid would be deposited in the body of fishes due to higher levels of lipids in the diet.

\subsection{Fatty acid composition}

A total fatty acids were identified in muscle tissue of Clarias batrachus fed with different diets are presented in Fig 1-7 and results suggests that the fillet profile changes as per the dietary sources of the fats fed to the fishes. In the earlier studies on fatty acids profiles of a marine fish, 15 fatty acids were identified by Gopakumar [23] and 19 were reported by Joydeep et al.[24]. In muscle tissue/carcass, the important and common essential fatty acids like Arachidionic acid (AA, 20:4n-6) was the principal n-6 PUFA at a level of $3.41-8.91 \%$ of total fatty acids. Eicosapentaenoic acid (EPA, 20:5n-3), and docosahexaenoic acid (DHA,22:6n-3) were the major n- 3 PUFA identified, accounting $0.52-3.29$ and $0.27-0.78$ respectively (Table 2 ). The fatty acid composition of fish carcass well known to be modified by dietary interventions [25], deficiency of nutrients in food [26] and nonfood nutrients like temperature[27]. It has been well documented that the PUFA content in fishes varied inversely with climatic temperature [17]. Climatic temperature changes is well known to vary the fatty acid profile of the carcass fish so that the unsaturation inversely changes with the temperature[28]. The lipid content in the muscle tissue recorded was decreased, the profile of EPA and DHA which are considered as human health beneficial essential fatty acids [20], recorded towards higher level. The EFA profile of $\mathrm{C}$. batrachus muscle was influenced by the lipids of the feed, reported for many species [29-33].The changes in EFA in the carcass of the C. batrachus fed with different fats types in the feed were recorded in the present study. This observation concurs with other fish with normal growth and development of body[34], and established the fact that the metabolic responses of carnivorous fish is set to at high level of intake protein as well [35].

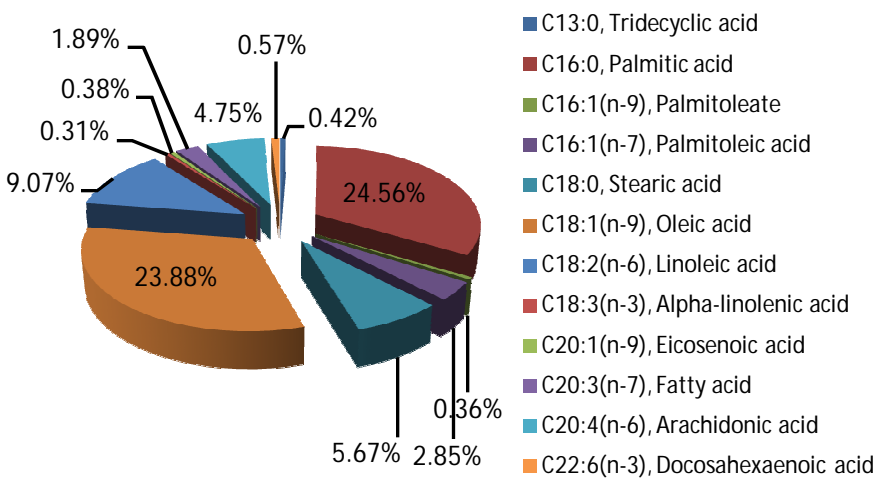

Fig. 1: Fatty acid profile of Clarias batrachus fed with $\mathrm{F}_{1}$ (FISOL).

It also shows that $\mathrm{C}$. batrachus has the ability to differentiate between intake fats, and using them for specific deposition and metabolizing for energy purposes, similar to the findings with many fish species [31,32,36]. Bell et al. [37] had reported that 
there is deposition of EFA were preferred substrates for oxidation in salmon. It is documented that feed FA proximate commonly impact that on the carcass, and changes in the FA composition of carcass in Clarias batrachus followed alteration in the dietary fats and also varied among carcass lipid classes as well demonstrated by Trushenski et al. [38,39] for a lean fillet fish sp. This conceptualized that $\mathrm{C}$. batrachus conforms to the metabolic responses in freshwater fish as ability of bioconversion and/or accumulation of dietary fats to $\mathrm{C} 20$ and C22 EFA as shown by others[40-42].

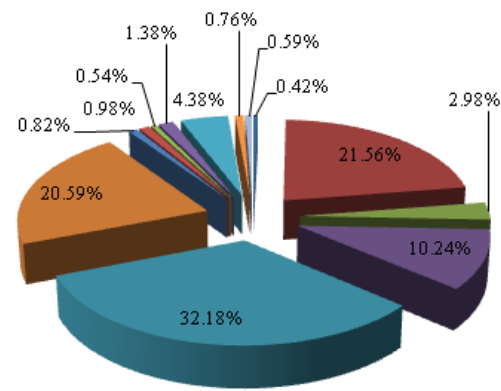

-C13:0 Tridecyclic acid -C16:0 Palmitic acid nC16:1(n-9)Palmitoleate $=$ C18:0 Stearic acid mC18:1(n-9)Oleic acid =C18:2(n-6) Linoleic acid $=\mathrm{C} 18: 3(\mathrm{n}-3)$ Alpha-linolenic acid -C20:1(n-9) Eicosenoic acid $=\mathrm{C} 20: 2(\mathrm{n}-7)$ Fatty acid

Fatty acid profile of Clarias batrachus in $\%$ ar ea $\quad \square \mathrm{C} 20: 3(\mathrm{n}-7)$ Fatty acid Fig. 2: Fatty acid profile of Clarias batrachus fed with $\mathrm{F}_{2}$ (BETAL).
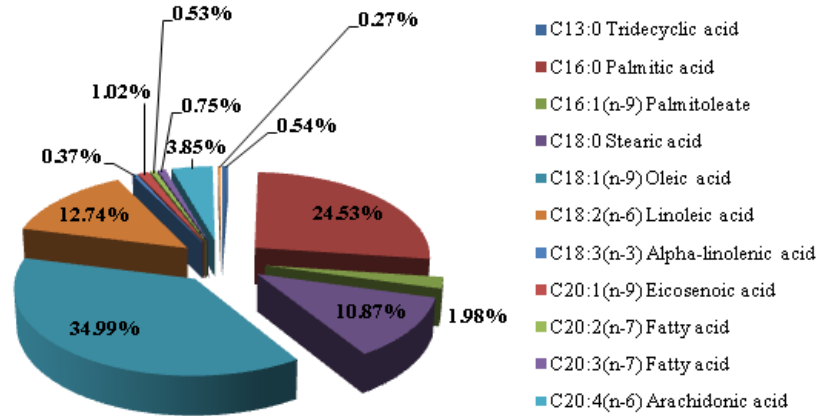

Fatty acid profile of Clarias batrachus in \% area $=\mathrm{C} 22: 6(\mathrm{n}-3)$ Docosahex aenoic acid

Fig. 3: Fatty acid profile of Clarias batrachus fed with $\mathrm{F}_{3}(\mathrm{SOYAL})$.

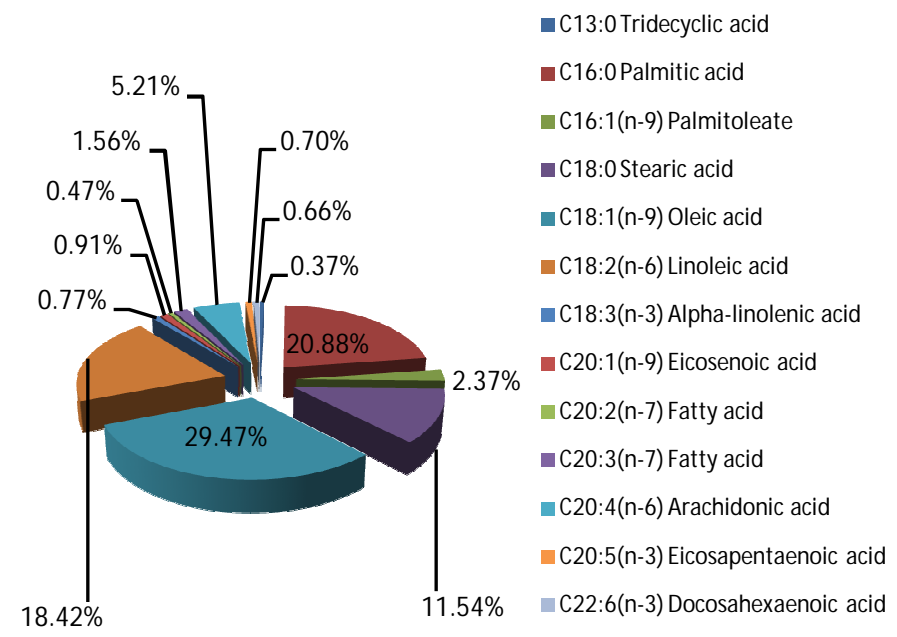

Fig. 4: Fatty acid profile of Clarias batrachus fed with $\mathrm{F}_{4}$ (LINOL).

Evaluation of poultry fat with cold-pressed linseed oil (LO) as supplemental dietary lipid for sablefish (Anoplopoma fimbria) reported by Friesen et al. [44]. The LO, has long been studied as an alternative source to FO in aquafeeds. But only in the last 10 years it has been used in diet for some species; sablefish [43-45]; seabream $[6,46]$, sea bass $[6,47]$ and turbot $[7,48,49]$. Results from these studies indicate that dietary oil/lipids can be partially substituted with LO, however, at higher substitution levels, reductions in growth may happen due to the deficiencies in n-3 HUFAs $[6,46,47,49,51]$. The effects of different dietary fats on the fatty acid profile of $C$. batrachus carcass have been investigated in the present study. In overall, this study showed that C. batrachus performed optimally on diets containing LINOL, MIXOL and FISOL with respect to deposition of EFA.

It can be concluded that out of six types of fats used in the present study, the MIXOL is considered best as a feed substitute in the artificial diets. The other fats have shown very mild to moderate level of changes in the fatty acid at $10 \%$ addition in the diet in a 12-week trial. Therefore, these fats may be used in combination with other fats to cut down the feed price and without effecting the survival, growth and carcass quality in terms of fatty acid profile of $\mathrm{C}$. batrachus.

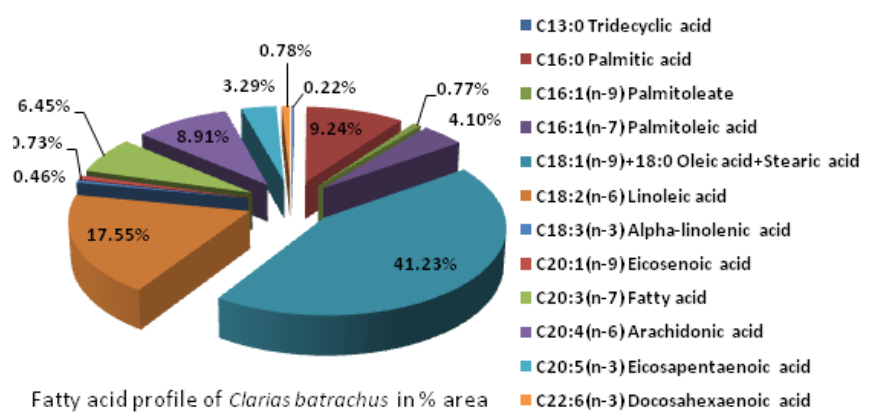

Fig. 5: Fatty acid profile of Clarias batrachus fed with $\mathrm{F}_{5}$ (MIXOL).
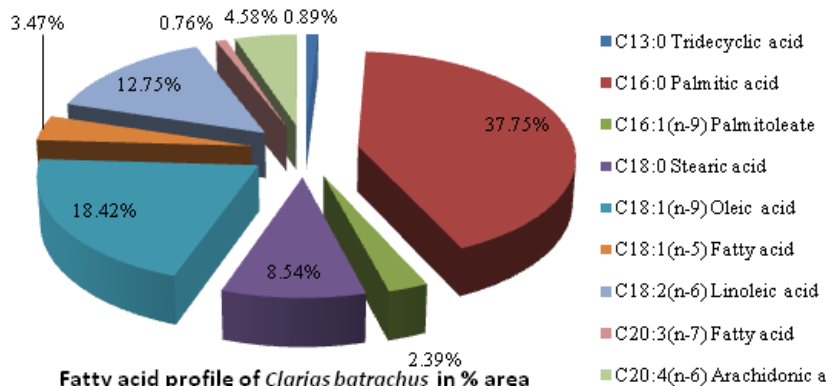

Fatty acid profile of Clarias batrachus in \% area $=\mathrm{C} 20: 4(\mathrm{n}-6)$ Arachidonic acid

Fig. 6: Fatty acid profile of Clarias batrachus fed with $\mathrm{F}_{6}$ (SATOL).

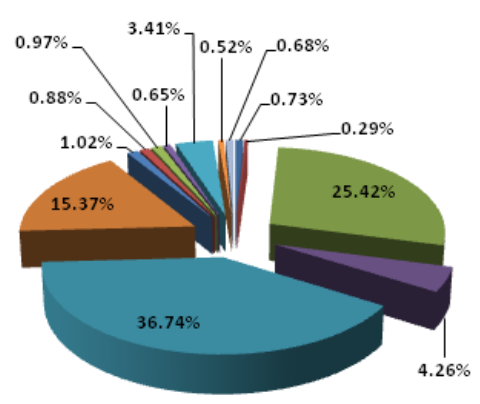

E13:0 Tridecyclic acid

- 15:0 Pentadecyclic acid

C16:0 Palmitic acid

E $16: 1(\mathrm{n}-9)$ Palmitoleate

=C18:1(n-9)+18:0 Oleic acid+Stearic acic

EC18:2(n-6) Linoleic acid

च C18:3(n-3) Alpha-linolenic acid

- C20:1(n-9) Eicosenoic acid

m $\mathrm{C} 20: 2(\mathrm{n}-7)$ Fatty acid

E $C 20: 3(n-7)$ Fatty acid

E $C 20: 4(\mathrm{n}-6)$ Arachidonic acid

$=\mathrm{C} 20: 5(\mathrm{n}-3)$ Eicosapentaenoic acid

Fatty acid profile of Clarias batrachus in \% area 1 C22:6(n-3) Docosahexaenoic acid

Fig. 7: Fatty acid profile of Clarias batrachus fed with $\mathrm{F}_{7}$ (NATFO). 


\section{CONCLUSION}

The observations, in the present study, suggest that manipulation with different dietary fat sources in the feed has direct relation with fatty acid profile and/or modifications in the carcass of $C$. batrachus grow-out fish.

\section{ACKNOWLEDGEMENTS}

Authors are very grateful to the Director, NBFGR, Lucknow for providing facilities to conduct this research work. Thanks also due to Ms. Madonna T. Thachil, Ph.D. scholar at CIFE, Mumbai for her support, and timely help for fatty acid analysis.

\section{REFERENCES}

1. Riche, M, Garling, D. North Central Regional Aquaculture Centre and United State Department of Agriculture USDA, 2003; pp 1-4.

2. Sarowar, MN, Jewel, MZH, Sayeed, MA, Mollah, MFA. Impacts of different diets on growth and survival of Channa striatus grow-outs, Int. J. Bio. Res. 2010; 1(3):08-12.

3. Aliyu-Paiko, M, Hashim, R, Alexandern, Shu Chien Chong,Yogarajah, L, Abdel Fattah, M, Sayed, EI. Influence of different sources and levels of dietary protein and lipid on the growth, feed efficiency, muscle composition and fatty acid profile of snakehead Channa striatus (Bloch, 1793) grow-out, Aquac. Res. 2010; 41(9):1365-1376.

4. Caballero, MJ, Obach, A, Rosenlund, G, Montero, D, Gisvold, M, Izquierdo, MS. Impact of different dietary lipid sources on growth, lipid digestibility, tissue fatty acid composition and histology of rainbow trout Onchorhynchus mykiss, Aquaculture.2002; 214:253271

5. Bell, JG, McGhee, F, Campbell, PJ, Sargent, JR. Rapeseed oil as an alternative to marine fish oil in diet of post-smoly atlantic salmon (Salmo salar): changes in flesh fatty acid composition and effectiveness of subsequent fish oil wash out, Aquaculture. 2003; 218:515-528.

6. Izquierdo, MS, Obach, A, Arantzamendi, L, Montero, D, Robaina, L, Rosenlund, G. Dietary lipid sources for seabream and seabass : growth performance, tissue composition and fish quality, Aqua.Nut., 2003; 9:397-407.

7. Regost, C, Arzel, J, Robien, J, Rosenlund, G, Kaushik, SJ.,. Total replacement of fish oil by soybean oil or linseed oil with a return to fish oil in turbot (Psetta maxima) I. Growth performances, flesh fatty acid profile and lipid metabolism, Aquaculture. 2003; 217:465-482.

8. Rafiquel Islam, Liton Kumar Mondol, Liton Sheikh, Sk. Shahinur Rahman, Mominul Islam and Atiqur Rahman. Identification of fatty acid profile, lipid characterization and nutritional status of Clarias batrachus, Nutritional Science and Food Technology. 2013; doi: 10.7243/2054-1848-1-1

9. Chedoloh, R., Karrila,T.T. and Pakdeechanuan, P. Fatty acid composition of important aquatic animals in Southern Thailand, International Food Research Journal. 2011; 18: 783-790.

10. Ashraf Suloma, Hiroshi Y Ogata. Lipid and Fatty Acid Composition of Commercially Important tropical Freshwater Fish Gonads: Guidelines for Specific Broodstock Diet. Turkish Journal of Fisheries and Aquatic Sciences. 2012; 12: 743-749. DOI: 10.4194/1303-2712v12-4-02.

11. Erkkila, AT, Lehto, S, Pyorala, K, Uusitupa, MI. N-3 Fatty acids and 5 -y risks of death and cardiovascular disease events in patients with coronary artery disease, Amer. J. Clinical Nutr..2003; 78:65-71.

12. Dallongeville, J, Yarnell, J, Ducimetiere, P, Arveiler, D, Ferriers, J, Montaye, M, Luc, G, Evans, A, Bingham, A, Hass, B. Fish consumption is associated with lower heart rates, Circulation. 2003;108(7):820-825.

13. James, MJ, Gibson, RA, Cleland, LG. Dietary polyunsaturated fatty acids and inflammatory media to reproduction, Amer. J. Clinical Nutr. 2000; 71:343S-348S

14. Nichols, PD, Mooney, BD, Elliott, NG. Nutritional value of Australian seafood II. Factors affecting oil composition of edible species, Report of the Fisheries Research and Development Corporation. CSIRO Marine Research, Hobart, Australia.2002;199 pp.

15. Exler, J, Kensella, JE, Watt, BK. Lipids and fatty acids of important finfish: new data for nutrient tables, J. Amer. Oil Chem. Soc. 1975; 52:154-159.

16. Bandara, NM, Batista, I, Nunes, ML, Empis, JM, Christie, W. Seasonal changes in lipid composition of sardine (Sardina pilchardus), J. Food Sci. 1997; 62:40-42.

17. Dunstan, GA, Olley, J, Ratkowsky, DA. Major environmental and biological factors influencing the fatty acid composition of seafood from Indo-Pacific to Antarctic waters, Rec. Res. Dev. Lipid Res.1999; 3:63-86.

18. Argungu, LA, Christianus A, Amin, SMN, Daud, SK, Siraj, SS, Aminur Rahman M. Asian Journal of Animal and Veterinary Advances. 2013; 8: 168-176. DOI: 10.3923/ajava.2013.168.176

19. Folch, JL, Sloane, M, Stanley, GHS. A simple method for the isolation and purification of total lipids from animal tissues, J. Biol. Chem. 1957; 226:497-509.

20. A.O.A.C. Official methods of analysis of Association of Official Analytical Chemists, Volume I, 16th edn. AOAC International, Arlington, USA, 1995.

21. Kleimenov, IY. Importance of fish as food. Moscow, Nauka. 1971.

22. Tanaka, S. Biological research on salmon sharks (Lamna ditropis). Report on the research of new resources development on shark, Japan Marine Fishery Resources Research Center, 1980; 59-84.

23. Gopakumar, K. Indian food fishes: Biochemical composition. Central Institute of Fisheries Technology. Indian Council of Agricultural Research, Cochin, India, 1997; 22- 28.

24. Joydeep, D, Debasish, P, Bhattacharya, A, Chakraborty, J, Banerjee, D, Ghosh, A. Comparative study onfatty acids and either lipids of fresh and sun-dried Bombay duck (Harpadon nehereus), J. Food Sci. Technol. 1999; 36 (6):506-510.

25. Olsen, Y, Skjervold, H. Variation in content of 3 fatty acids in farmed Atlantic salmon, with special emphasis one effects on non-dietary factors, Aquacult. Int. 1995; 3:22-35.

26. De Silva, SS, Gunasekera, RM, Collins, R, Ingram, BA, Austin, CM Changes in the fatty acid profile of the Australian short fin eel in relation to development, J. Fish Biol. 1997; 50 (5) : 992-998.

27. Bell, MV, Henderson, RJ, Sargent, JR. The role of polyunsaturated fatty acids in fish, Com. Biochem. Physiol. 1996; 83B:711-719.

28. Morris, RJ, Culkin, F. Fish. In: Ackman R. G (Ed.), Marine biogenic lipids, fats and oils, CRC Press, Boca Raton, Florida, 1989; 145-178.

29. Watanabe, T. Lipid nutrition in fish, Comp. Biochem. Physiol. 1982; 73B:3-15.

30. Morais, S, Bell, JG, Robertson, DA, Roy, WJ, Morris, PC Protein/lipid ratios in extruded diets for Atlantic cod, Gadus morhua L. Effects on growth, feed utilization, muscle composition and liver histology, Aquaculture. 2001; 203:101-119.

31. Rosenlund, G, Obach, A, Sandberg, MG, Standal, H, Tveit, K. Effect of alternative lipid sources onlong-term growth performance and quality of Atlantic salmon (Salmo salar L.), Aqua. Res. 2001; 32(Suppl.1), 323-328.

32. Bell, JG, Henderson, RJ, Tocher, DR, McGhee, F, Dick, JR, Porter, A, Smullen, RP, Sargent, JR. Substituting fish oil with crude palm oil in the diet of Atlantic salmon (Salmo salar) affects muscle fatty acid composition and hepatic fatty acid metabolism, J.of Nutr. 2002; 132: 222-230

33. Caballero, MJ, Obach, A, Rosenlund, G, Montero, D, Gisvold, M, Izquierdo, MS. Impact of different dietary lipid sources on growth, lipid digestibility, tissue fatty acid composition and histology of 
rainbow trout, Oncorhynchus mykiss, Aquaculture. 2002; 214: 253271.

34. Sargent, JR, Henderson, RJ, Tocher, DR. The lipids. In: Fish Nutrition (ed. by J.E. Halver),1989; 154-218. Academic Press, New York, NY, USA.

35. Bibiano Melo, JF, Lundstedt, LM, Meton, I, Baanante, IV, Oraes, G. Effects of dietary levels of protein on nitrogenous metabolism of Rhamdiaquelen (Teleostei: Pimelodidae). Comparative Biochemistry and Physiology-Part A: Molecular \& Integrative Physiology. 2006;145:181-187.

36. Torstensen, BE, Fryland, L, Lie, O. Replacing dietary fish oil with increasing levels of rapeseed oil and olive oil effects on Atlantic salmon (Salmo salar) tissue and lipoprotein composition and lipogenic enzyme activities, Aqua. Nutr. 2004;10 : 175-192.

37. Bell, JG, Henderson, RJ, Tocher, DR, McGhee, F, Dick, JR, Porter, A, Smullen, RP, Sargent, JR. Replacement of fish oil with rapeseed oil in diets of Atlantic salmon (Salmo salar) affects tissue lipid composition and hepatocyte fatty acid metabolism, Jour. of Nutr. 2001; 132: 222-230.

38. Trushenski, JT, Lewis, HA, Kohler, CC. Fatty acid profile of sunshine bass: I. Profile change is affected by initial composition and differs among tissues, Lipids. 2008a; 43:629-641.

39. Trushenski, JT, Lewis, HA, Kohler, CC. Fatty acid profile of sunshine bass: II. Profile change differs among fillet lipid classes,. Lipids. 2008b; 43: 643-653.

40. Mourente, $\mathrm{G}$, Tocher, DR. In vivo metabolism of [1-14C] linolenic acid (18:3(n-3) and [1-14C] eicosapentaenoic acid (20:5(n-3)) in a marine fish: time course of the desaturation /elongation pathway, Biochimica. et Biophysica. Acta. 1994; 1212:109-118.

41. Mourente, G, Tocher, DR. The in vivo incorporation and metabolism of [1-14C] linolenate (18: 3n-3)in liver, brain and eyes of juveniles of rainbow trout Onchorhynchus mykiss L. and gilthead sea bream Sparus aurata L, Fish Physiol. and Biochem. 1998; 18:149-165.

42. Tocher, DR, Ghioni, C. Fatty acid metabolism in marine fish: low activity of fatty acyl D5 desaturation in gilt head sea bream (Sparus aurata) cells, Lipids. 1999; 34: 433-440.

43. Friesen, EN, Balfry, SK, Skura, BJ, Ikonomou, MG, Higgs, DA. Evaluation of cold-pressed flax seed oil as an alternative dietary lipid source for juveniles able fish (Anoplopoma fimbria). Aquaculture Research., 2011; doi: 10.1111/j.1365-2109.2011.03022.x.

44. Friesen, Erin N, Shannon, K, Balfry, Brent J, Skura, Michael G., Ikonomou, Dave, Higgs, A. Evaluation of cold-pressed flaxseed oil as an alternative dietary lipid source for juveniles able fish (Anoplopoma fimbria), Aqua. Res. 2013a; 44:182-199.

45. Friesen Erin N, Shannon, K, Balfry, Brent J, Skura, Michael, Ikonomou, Dave, Higgs, A. Evaluation of poultry fat and blends of poultry fat with cold-pressed flaxseed oil as supplemental dietary lipid sources for juveniles able fish (Anoplopoma fimbria), Aqua. Res., 2013b; 44:300-316.
46. Izquierdo, MS, Montero, D, Robaina, L, Caballero, MJ, Rosenlund, G, Gine's, R. Alterations in fillet fatty acid profile and flesh quality in gilthead seabream (Sparus aurata) fed vegetable oils for a long period. Recovery of fatty acid profiles by fish oil feeding, Aquacture. 2005; 250:431-444.

47. Montero, D, Robaina, L, Caballero, MJ, Gines, R, Izquierdo, MS. Growth, feed utilization and flesh quality of European sea bass (Dicentrarchus labrax)fed diets containing vegetable oils: a timecourse study on the effect of a re-feeding period with a $100 \%$ fish oil diet. Aquaculture. 2005; 248:121-134.

48. Bell, JG, Tocher, DR, MacDonald, FM, Sargent, JR. Effects of diets rich in linoleic $(18: 2 n-6)$ and $\alpha$-linolenic $(18: 3 n-3)$ acids on the growth, lipid class and fatty acid compositions and eicosanoid production in juvenile turbot (Scophthalmus maximus L.), Fish Physiol. and Biochem. 1994; 13:105-118.

49. Bell, JG, Tocher, DR, Farndale, BM, McVicar, AH, Sargent, JR. Effects of essential fatty acid-deficient diets on growth, mortality, tissue histopathology and fatty acid compositions in juvenile turbot (Scophthalmus maximus), Fish Physiol. and Biochem. 1999; 20:263277.

50. Dayal, R, Srivastava, PP, Bhatnagar, A, Chowdhary, S, Yadav, AK, Jena, JK. Influence of different sources of dietary lipid on the growth, feed efficiency and survival of snakehead, Channa striatus (Bloch, 1793) grow-out, Natl. Acad. Sci. Letters 2012; 35(6) : 541-546.

51. Srivastava, PP, Dayal, R, Bhatnagar, A, Chowdhary, S, Yadav, AK, Lakra, Sw. Influence of different dietary fats on fatty acid profile of striped snakehead (Channa striatus) fish carcass, Int. J. of Biochem. \& Biophys. 2014; 2(4) : 31-40.

\section{How to cite this article:}

P.P. Srivastava, Akhilesh K. Yadav, Shipra Chowdhary, Pradeep Shrivastava, R. Dayal, G. Venkateshwarlu, W. S. Lakra. Impact of dietary fats on fatty acids profile of threatened Asian cafish (Clarias batrachus, Linnaeus, 1758). J App Biol Biotech. 2014; 2 (05): 015-020. 